\title{
Promising Future of Fluoropolymers
}

\author{
Bruno Améduri \\ Ingénierie et Architectures Macromoléculaires, Institut Charles Gerhardt, Ecole Nationale \\ Supérieure de Chimie de Montpellier (UMR5253-CNRS), UM, 240 rue Emile Jeanbrau, \\ 34296 Montpellier Cedex 5, France.
}

\begin{abstract}
This article aims at showing the usefulness of fluoropolymers (PFs), supplying a browse on their synthesis, applications and recycling. FPs are currently prepared by conventional radical polymerization of fluoromonomers. These specialty polymers, produced in low tonnage compared to that of commodity ones, display outstanding properties such as chemical, oxidative and thermal resistances, low refractive index, dissipation factor, permittivity, and water absorptivity, and excellent weatherability and durability. More recent routes for their preparations are suggested, controlled or not, leading to random, alternated, block, graft, dendrimers or multiarm copolymers, as well as their applications ranging from coatings to high performance (thermoplastic) elastomers, energy related-materials (e.g. fuel cell membranes, components for Lithium ion batteries, electroactive devices, and photovoltaics) to original and surfactants, optical devices, organic electronics, composites and shape memory polymers.
\end{abstract}

Keywords: advanced materials; elastomers; energy; fuel cell membranes; fluoropolymers; radical polymerization; surface materials; thermal properties.

\section{Introduction}

In the last decades, novel materials that display the suitable property for a specific application have led to an increasing interest. Among them, fluoropolymers are relevant niche candidates endowed with outstanding properties (Table 1) ${ }^{[1-9]}$ such as thermal stability, chemical inertness (to solvents, oils, water, acids and bases), low values of the refractive index, permittivity, dissipation factor and water absorptivity, as well as excellent weatherability, resistance to oxidation and durability. Hence, they have been involved in many High-Tech applications (Table 1): protective coatings, fuel cell membranes, elastomers, ${ }^{[10-12]}$ fabrics, specific items in automotive industries ${ }^{[5]}$ (350 g of FP per car such as seals, gaskets, or transmission components, as well as cables and hoses, and increasing amounts of items as fuel cell membranes and electrolytes and separators of lithium ions batteries), aerospace and aeronautics (fire retardant-coatings, elastomers for gaskets or O- 
rings and cables, considered as an average of $1 \mathrm{~km}$-cables made of FPs per passenger in planes), microelectronics, petrochemical, chemical engineering (high performance membranes), ${ }^{[13]}$ textile treatment, protective building coatings (e.g. paints resistant to UV and to graffiti or liners in oil tanks of vehicules), and optics (core and cladding of optical fibres). ${ }^{[14]}$

This contribution supplies an overview of PFs in terms of synthesis, applications and recyclability to highlight how these relevant materials have become essential nowadays.

The fluoromonomer precursors are currently prepared from synthons obtained by fluorination, hydrofluoric acid being produced from calcium fluoride, as follows:

$$
\mathrm{CaF}_{2}(\mathrm{sol})+\mathrm{H}_{2} \mathrm{SO}_{4}(\mathrm{liq}) \rightarrow \mathrm{CaSO}_{4}(\mathrm{sol})+2 \mathrm{HF} \text { (gas) }
$$

Since reported in many reviews ${ }^{[3,5-6,9,15]}$, the synthesis of fluorinated monomers [as tetrafluoroethylene (TFE), vinylidene fluoride (VDF), chlorotrifluoroethylene (CTFE), 3,3,3trifluoropropene (TFP), hexafluoropropylene (HFP), trifluoroethylene (TrFE)] are not mentioned. They are commercially available and conventional alkenes that contain one or several fluorine atoms born by ethylenic carbon atoms have also been designed on demand for specific applications. They are usually gaseous $(<4$ carbon atoms) and their mode of synthesis is costly.

Most FPs are synthesized by radical (co)polymerization of fluoroalkenes (except those based on hexafluoropropylene oxide (section 2.4; Scheme 5) and fluorinated oxetanes achieved by ionic initiations).

Actually, two main classes of FPs can be taken into account: i) PFs where the fluorinated groups are located in the polymer backbone (e.g. most homopolymers based on TFE, CTFE, VDF, and TrFE): they exhibit good thermal stability, chemical inertness, low refractive index, and dielectric constant, and ii) FPs that contain a fluorinated dangling group [poly(meth)acrylates or poly(styrene)s bearing perfluorinated side chains ${ }^{[1,3,5,8]}$ that brings better surface properties.

FPs are specialty polymers which represent ca. less than $4 \%$ of all macromolecules. In 2012, their production was 223,000 tons while it is forecast to be ca. double $(>405,000 \mathrm{t}$ ) by 2022. ${ }^{[16]}$ Figure 1 sums up the production of different classes of FPs, PTFE being the most produced, while Figure 2 exhibits the FPs consumption per industry in Europe in 2019. 


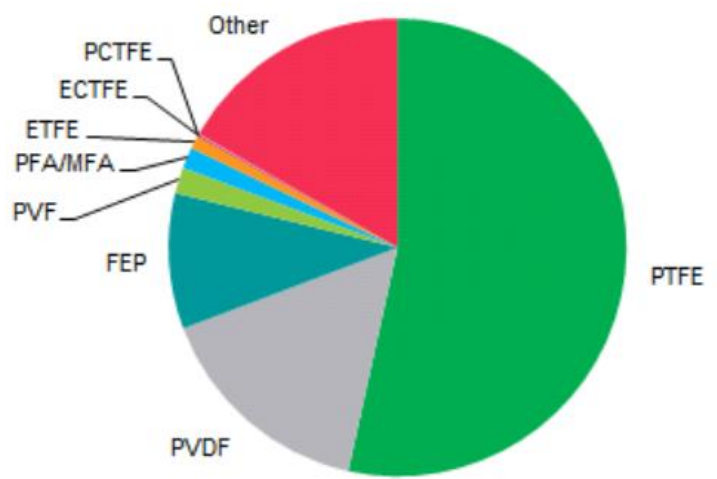

Figure 1: global situation of the production of various FPs (2019) ${ }^{\lfloor 16\rfloor}$

Figure 3 represents the fast growing market for high performance FPs to 2024. Table 1 lists the commercially available FPs and Table 2 their specific uses, properties and applications.

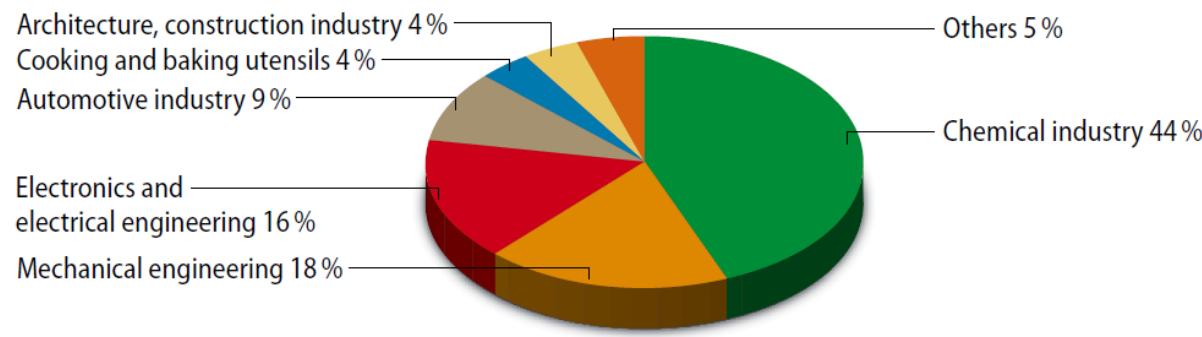

Figure 2: Fluoropolymers consumption per industry in Europe (2015). Reproduced with permission from Kunststoffe ${ }^{[17]}$

Table 1: Commercially available fluoropolymers (from ${ }^{[18]}$ )

\begin{tabular}{|c|c|c|c|c|}
\hline & Monomer(s) & $m p,{ }^{\circ} \mathrm{C}$ & $\begin{array}{l}\text { Max. Applic. } \\
\text { Temp. }{ }^{\circ} \mathrm{C} \\
\end{array}$ & $\begin{array}{l}\text { Sales Volume } \\
\text { (thousands of tons) }\end{array}$ \\
\hline $\begin{array}{l}\text { Nonmelt processable PTFE } \\
\text { PTFE } \\
\text { modified PTFE }\end{array}$ & $\begin{array}{l}\text { TFE } \\
\text { TFE + PPVE (<1 w\%) }\end{array}$ & $\begin{array}{l}327 \\
326\end{array}$ & $\begin{array}{l}260 \\
260\end{array}$ & \} 126 \\
\hline $\begin{array}{l}\text { Melt processable fluorother } \\
\text { PFA } \\
\text { MFA } \\
\text { FEP } \\
\text { ETFE } \\
\text { THV } \\
\text { PVDF } \\
\text { PVF } \\
\text { PCTFE } \\
\text { ECTFE }\end{array}$ & $\begin{array}{l}\text { noplastics } \\
\text { TFE + PPVE } \\
\text { TFE + PMVE } \\
\text { TFE + HFP } \\
\text { TFE + E } \\
\text { TFE + HFP + VDF } \\
\text { VDF } \\
\text { VF } \\
\text { CTFE } \\
\text { CTFE + E }\end{array}$ & $\begin{array}{l}305 \\
285 \\
270 \\
270 \\
120-220 \\
170 \\
190 \\
210 \\
240\end{array}$ & $\begin{array}{l}260 \\
250 \\
200 \\
150 \\
\\
150 \\
110 \\
200 \\
150\end{array}$ & $\begin{array}{l}3_{6} \\
19 \\
7 \\
1 \\
36 \\
5 \\
6 \\
2\end{array}$ \\
\hline $\begin{array}{l}\text { Amorphous fluoropolymer } \\
\text { Teflon } A F^{(B)} \\
{\text { Hyflon } A D^{(B)}}^{\text {Cytop }^{(B)}}\end{array}$ & $\begin{array}{l}\text { PDD + TFE } \\
\text { TTD + TFE } \\
\text { PBVE }\end{array}$ & $\begin{array}{l}T_{\mathrm{g}},{ }^{\circ} \mathrm{C} \\
160-240 \\
90-125 \\
108\end{array}$ & $\begin{array}{l}260 \\
250\end{array}$ & \}$_{<1}$ \\
\hline $\begin{array}{l}\text { Amorphous, curable fluorop } \\
\text { FKM }\end{array}$ & $\begin{array}{l}\text { olymer } \\
\text { VDF + HFP + cure package } \\
\text { TFE + VDF + HFP + cure package } \\
\text { TFE + VDF + perfluoro vinylethers } \\
\text { TFE + P + cure package } \\
\text { TFE + PMVE + functional monomer } \\
\text { + cure package }\end{array}$ & $\begin{array}{l}T_{\mathrm{g}},{ }^{\circ} \mathrm{C} \\
-20 \\
-10 \\
-40 \\
-10 \\
-5\end{array}$ & $\begin{array}{l}150 \\
150\end{array}$ & $\begin{array}{l}\} \\
<0,05\end{array}$ \\
\hline
\end{tabular}




\section{HIGH PERFORMANCE FLUOROPOLYMERS (HPF) MARKET, BY REGION (USD BILLION)}

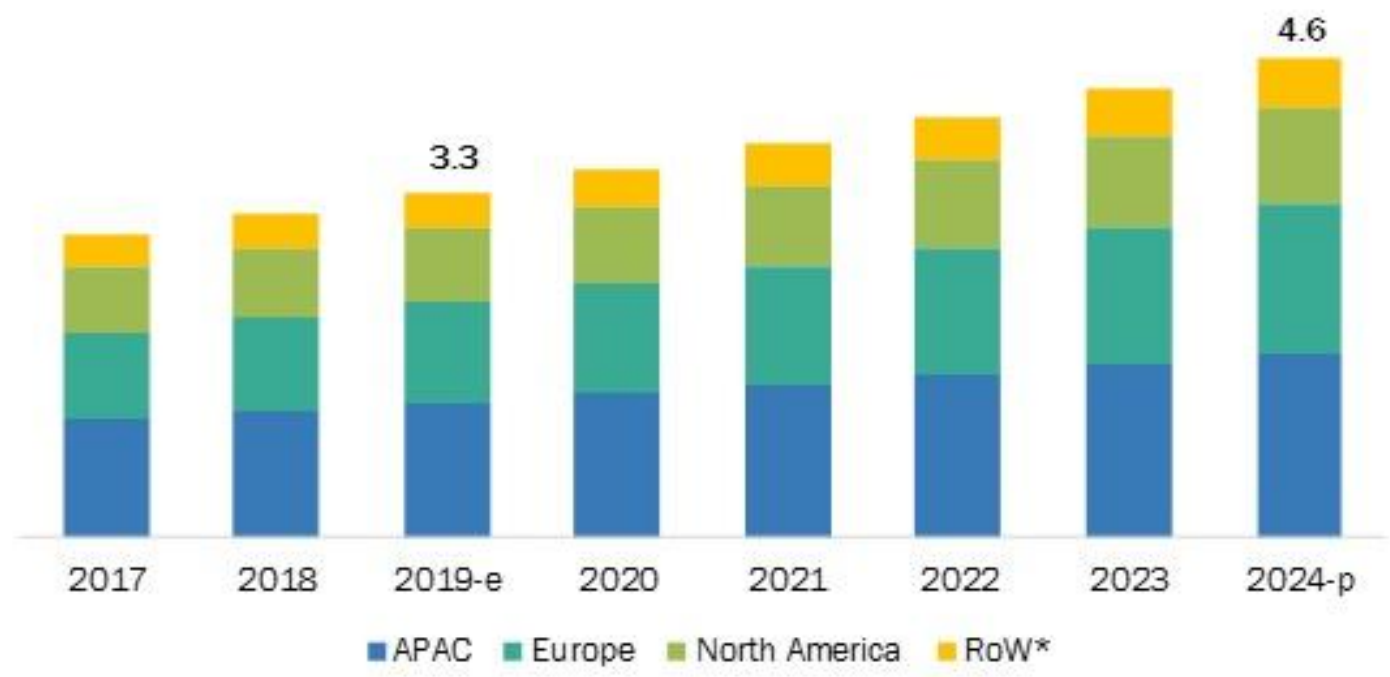

e-estimated, p-projected RoW* includes South America, Middle East, and Africa

Figure 3: evolution and prediction of production of high performance FPs from ref ${ }^{[16]}$ (APAC stands for Asia Pacific accreditation cooperation)

Table 2: Major domains, properties and industrial applications from fluoropolymers ${ }^{[18] a)}$

\begin{tabular}{|c|c|c|c|}
\hline $\begin{array}{l}\text { Industry/ } \\
\text { Application domains }\end{array}$ & Searched properties & Specific uses & $\begin{array}{l}\text { Used } \\
\text { Fluoropolymers }\end{array}$ \\
\hline $\begin{array}{l}\text { Chemical/Petrochemical } \\
\text { Industry }\end{array}$ & $\begin{array}{l}\text { Chemical Resistance } \\
\text { Good Mechanical Properties } \\
\text { Thermal Stability } \\
\text { Cryogenic Properties }\end{array}$ & $\begin{array}{l}\text { Gaskets, vessel liners, } \\
\text { pumps, valve and pipe liners, } \\
\text { tubings, coatings, expansion } \\
\text { joints/bellows, } \\
\text { heat exchangers }\end{array}$ & $\begin{array}{l}\text { PTFE, PFA/MFA } \\
\text { ETFE, ECTFE } \\
\text { FEP } \\
\text { FKM, FFKM } \\
\text { TFE-P }\end{array}$ \\
\hline Electrical/Electronic Industry & $\begin{array}{l}\text { Low Dielectric Constant } \\
\text { High Volume/Surface Resistivity } \\
\text { High Dielectric Breakdown } \\
\text { Voltage } \\
\text { Flame Resistance, Thermal } \\
\text { stability } \\
\text { Low refractive indices }\end{array}$ & $\begin{array}{l}\text { Wire and cable Insulation, } \\
\text { connectors, optical fibres, } \\
\text { printed circuit boards }\end{array}$ & $\begin{array}{l}\text { FEP, PTFE, PFA, MFA } \\
\text { ETFE, ECTFE } \\
\text { PCTFE } \\
\text { amorphous FP }\end{array}$ \\
\hline Automotive/Aircraft Industry & $\begin{array}{l}\text { Low Coefficient of Friction } \\
\text { Good Mechanical Properties } \\
\text { Cryogenic Properties, } \\
\text { Chemical Resistance } \\
\text { Low permeation properties }\end{array}$ & $\begin{array}{l}\text { Seals, O-Rings, hoses in } \\
\text { automotive power steering, } \\
\text { transmissions, and } \\
\text { airconditioning, } \\
\text { bearings, sensors } \\
\text { fuel management systems. }\end{array}$ & $\begin{array}{l}\text { FKM, PTFE } \\
\text { FFKM } \\
\text { THV }\end{array}$ \\
\hline Coatings & $\begin{array}{l}\text { Thermal/Weather Stability } \\
\text { Low Surface Energy } \\
\text { Chemical Resistance }\end{array}$ & $\begin{array}{l}\text { Cookware coatings, } \\
\text { coatings of metal surfaces, } \\
\text { powder coatings }\end{array}$ & $\begin{array}{l}\text { PTFE } \\
\text { PVDF, ETFE } \\
\text { FEVE, PFA }\end{array}$ \\
\hline Medical & Low Surface Energy, & Cardiovascular grafts, heart & PTFE, \\
\hline
\end{tabular}




\begin{tabular}{|c|c|c|c|}
\hline $\begin{array}{l}\text { Industry/ } \\
\text { Application domains }\end{array}$ & Searched properties & Specific uses & $\begin{array}{l}\text { Used } \\
\text { Fluoropolymers }\end{array}$ \\
\hline & $\begin{array}{l}\text { Stability, Purity } \\
\text { Excellent Mechanical Properties } \\
\text { Chemical Resistance }\end{array}$ & $\begin{array}{l}\text { patches, ligament } \\
\text { replacement } \\
\text { packaging films for medical } \\
\text { products }\end{array}$ & PCTFE \\
\hline $\begin{array}{l}\text { General Architectural/Fabric/ } \\
\text { Film applications }\end{array}$ & $\begin{array}{l}\text { Excellent Weatherability } \\
\text { Flame Resistance } \\
\text { Transparency } \\
\text { Low Surface Energy } \\
\text { Barrier properties }\end{array}$ & $\begin{array}{l}\text { Coated fabrics and films for } \\
\text { buildings/roofs, front/backside } \\
\text { films for solar applications }\end{array}$ & $\begin{array}{l}\text { ETFE, PTFE, PVDF } \\
\text { PCTFE, PVF, THV }\end{array}$ \\
\hline Polymer additives & $\begin{array}{l}\text { Low coefficient of Friction } \\
\text { Flame Resistance } \\
\text { Abrasion resistance } \\
\text { Antistick properties }\end{array}$ & $\begin{array}{l}\text { Polyolefin processing to avoid } \\
\text { surface defects and for faster } \\
\text { processing. } \\
\text { Additives for inks, coatings, } \\
\text { lubricants, } \\
\text { anti-dripping agents }\end{array}$ & $\begin{array}{l}\text { THV, FKM } \\
\text { PVDF, PTFE }\end{array}$ \\
\hline Semiconductor Industry & $\begin{array}{l}\text { Chemical Resistance } \\
\text { High Purity } \\
\text { Antiadhesion, Insulation, barrier } \\
\text { properties } \\
\text { Thermal Stability }\end{array}$ & $\begin{array}{l}\text { Process surfaces } \\
\text { wafer carriers } \\
\text { tubing, valves, pumps and } \\
\text { fittings, } \\
\text { storage tanks }\end{array}$ & $\begin{array}{l}\text { PFA, ECTFE } \\
\text { PCTFE, PTFE } \\
\text { amorphous FP }\end{array}$ \\
\hline $\begin{array}{l}\text { Energy conversion/storage } \\
\text { Renewable Energies }\end{array}$ & $\begin{array}{l}\text { Chemical/thermal resistance } \\
\text { ion-transportation } \\
\text { high weatherability } \\
\text { high transparency } \\
\text { corrosion resistance }\end{array}$ & $\begin{array}{l}\text { Binder for electrodes, } \\
\text { separators, } \\
\text { ion-selective membranes, } \\
\text { gaskets, membrane- } \\
\text { reinforcements, } \\
\text { films for photovoltaics } \\
\text { coatings for wind mill blades }\end{array}$ & $\begin{array}{l}\text { PVDF, Fluoroionomers } \\
\text { (PFSA) ,THV, ETFE } \\
\text { ECTFE, PTFE, FEP } \\
\text { PVF }\end{array}$ \\
\hline
\end{tabular}

a) Tetrafluoroethylene (TFE), vinylidene fluoride (VDF), chlorotrifluoroethylene (CTFE), 3,3,3-trifluoropropene (TFP), hexafluoropropylene (HFP), trifluoroethylene (TrFE), perfluoromethyl vinyl ether (PMVE), ethylene (E), perfluorosulfonic acid (PFSA), poly(VDF-ter-HFP-ter-TFE) terpolymers (THV).

\section{Applications}

This section shows how specific FPs synthesized on demand can fulfill the searched applications and is illustrated by several examples below.

\subsection{Thermoplastics}

Thermoplastics are melt processable (except $\mathrm{PTFE}^{[15]}$ ) was can be processed by sintering since its molten state of ca. $60{ }^{\circ} \mathrm{C}$ above its melting point $\left(327{ }^{\circ} \mathrm{C}\right)$ may further induce its decomposition. Critical physical properties of fluorinated (co)polymers and perfluoropolymers as well as their thermal, mechanical, and physical properties have been supplied in a book chapter. ${ }^{[19]}$ Thus, copolymerizing HFP or perfluoroalkyl vinyl ethers (PAVEs) with TFE led to FEP and PFA, respectively, that exhibit lower melting points (coming from a poorer organization brought by $\mathrm{CF}_{3}$ and $\mathrm{OC}_{n} \mathrm{~F}_{2 \mathrm{n}+1}$ bulky side groups).

Usually, though valuable materials, most fluorinated homopolymers display some drawbacks, as (per)fluorinated homopolymers show a high crystallinity content (mainly linked to the organization from the symmetry of monomer units), which imparts a low solubility in 
common organic solvents (thus affecting their chromatographic, viscosimetric and some spectroscopic analyses) and their crosslinking can be limited. Hence, the production of fluorinated copolymers ${ }^{[20]}$ (composed of mixture of comonomers enabling to incorporate bulky side-groups that induce disorder in the macromolecule hence lowering or suppressing that high crystallinity of homopolymers) has not stopped, increasing without showing the drawbacks of aforementioned homopolymers.

Thus, strategies to copolymerize commercially available fluoroalkenes with functional monomers is still of growing interest as the function brings a complementary property. Synthesis and applications of copolymers of TFE have recently been reviewed in the excellent book chapter from Thrasher's team ${ }^{[20]}$ in addition to copolymers of CTFE ${ }^{[21]}$, of VDF ${ }^{[22-23]}$ (Scheme 1) (or terpolymers from VDF and trifluoroethylene, $\operatorname{TrFE}^{[24]}$ ).

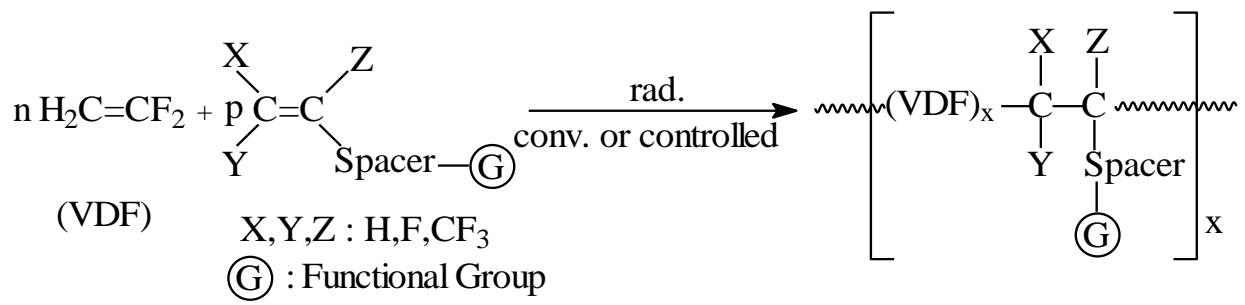

Scheme 1: radical copolymerization of vinylidene fluoride (VDF) with (fluoro)functional comonomers (where $\mathrm{G}$ stands for $\mathrm{SO}_{3} \mathrm{H}, \mathrm{P}(\mathrm{O})(\mathrm{OEt})_{2}, \mathrm{Br}, \mathrm{CO}_{2} \mathrm{H}$, cyclocarbonate, oligo(ethylene oxide), oligo(HFPO), $\mathrm{Si}(\mathrm{OEt})_{3}$, and $\left.\mathrm{NR}_{3}{ }^{+}\right)^{[22-23,25]}$

Besides most fluorinated comonomers, a relevant ideal partner for VDF, functional 2trifluoromethacrylates (Scheme 2) have recently led to valuable materials ${ }^{[25]}$ finding significant applications as adhesives ${ }^{[26]}$, hydrophobic ${ }^{[27]}$ and anticorrosion ${ }^{[28]}$ coatings, as well as gel polymer electrolytes for Lithium ion batteries. ${ }^{[29]}$

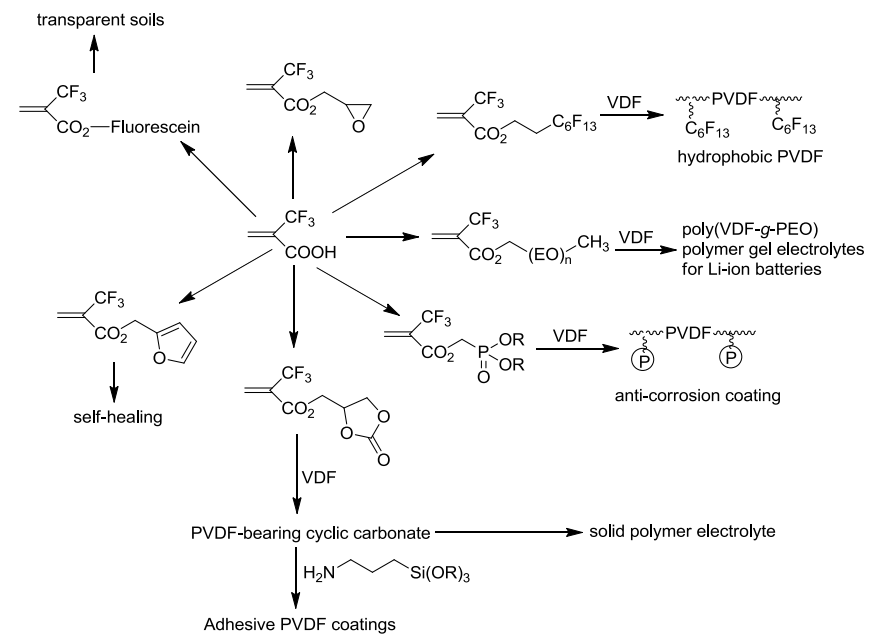


Scheme 2: Synthesis of various functional 2-trifluoromethacrylates (MAF-esters) from 2trifluoromethacrylic acid and their radical copolymerizations with VDF for specific materials. [25]

In addition, a growing research aims at synthesizing FPs containing phosphorous atoms which bring complementary properties such as high acidity (case of phosphonic acids), complexation, anticorrosion, flame retardant, and biomedical applications (Scheme 3) ${ }^{[30]}$.

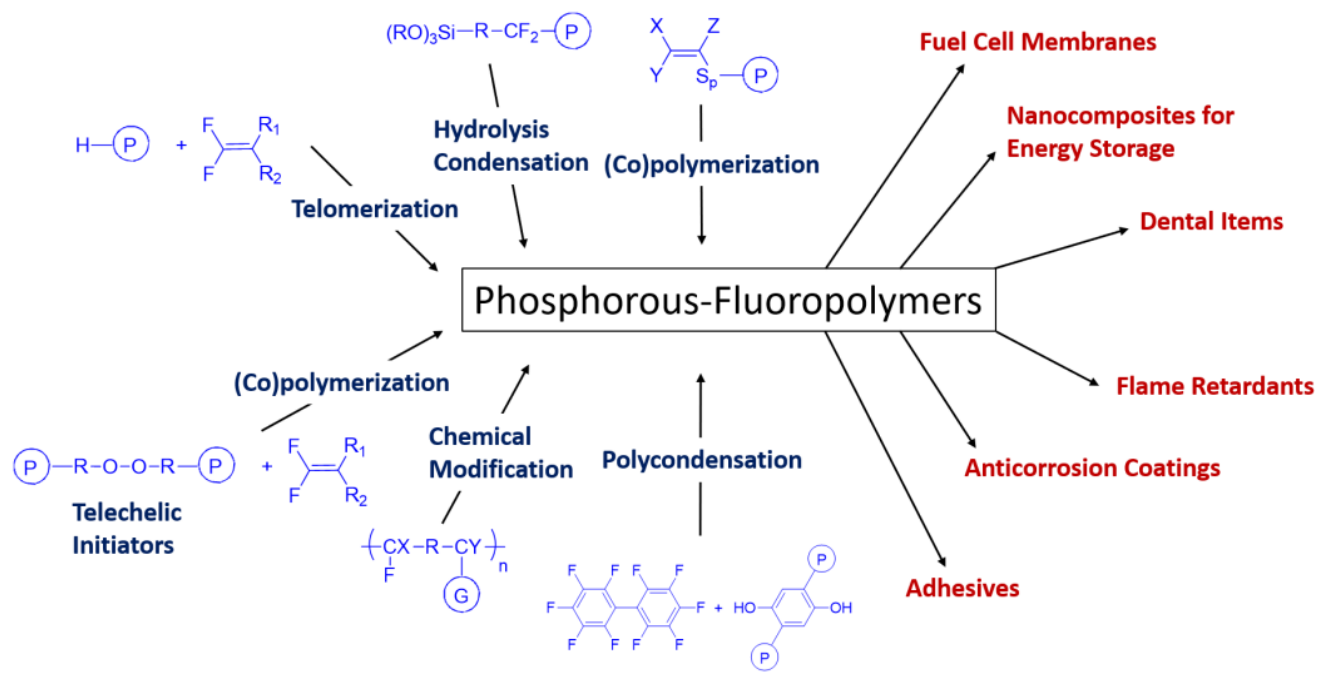

Scheme 3: strategies of syntheses and applications of phosphorous-containing fluoropolymers. ${ }^{[30]}$

\subsection{Coatings}

FPs have also been used in formulations for paints and coatings: thermoplastics as PTFE in planes, poly(vinyl fluoride), PVF, and PVDF for backsheets in photovoltaic panels (section 2.4.4.), antigraffiti paints and PVDF for buildings because of its high UV resistance, as well as a more recent generation of paints produced from containing CTFE and functional vinyl ether units. ${ }^{[31]}$ Actually, the structure is alternated (Figure 4) because of the reactivity of an electron withdrawing CTFE (or TFE) and electron donating vinyl ethers. The corresponding tradenames are Lumiflon $₫$ (guaranteed for 30 years) and Zeffle $§$, marketed by Asahi Glass Company and Daikin, respectively. While the fluorinated units display weatherability, durability, and chemical inertness, these functional VEs have been smartly chosen from their functions bringing complementary properties (gloss, hardness, solubility, crosslinking, compatibility with pigments). 


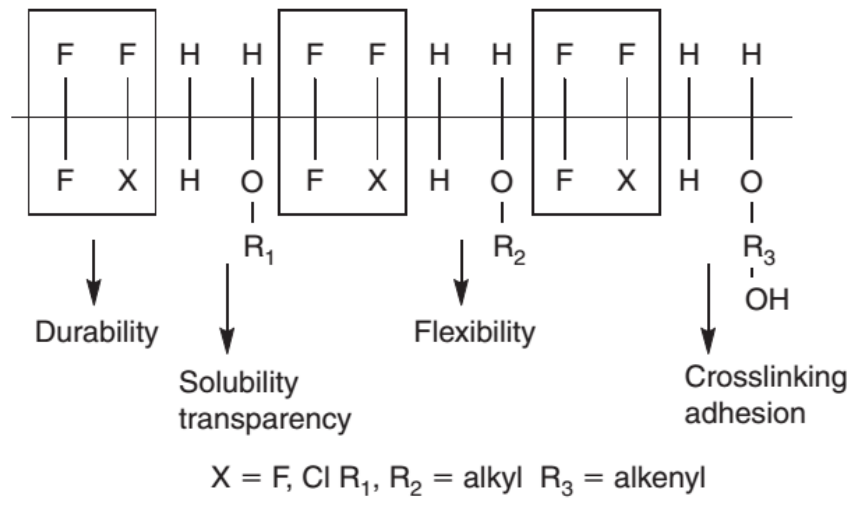

Figure 4: structures of alternated poly(CTFE or TFE-alt-VE) copolymers, exemplified by Lumiflon® or Zeffle® paints . ${ }^{[31]}$

\subsection{Fluorinated Elastomers}

Fluorinated elastomers play a major part in nowadays life. About $45 \%$ of U.S. fluorocarbon elastomer consumption is devoted in ground transportation. ${ }^{[32]}$ Various classes are commercially available ${ }^{[4,7,11]}$ (Table 3) ranging from fluorocarbon elastomers to fluorosilicones [e.g. poly(3,3,3-trifluoropropyl methyl siloxane, or hybrid fluorosilicones $\left.(\text { Scheme } 4)^{[33]}\right]$ and fluorophosphazenes. ${ }^{[34]}$

Table 3: Thermal properties and suppliers of fluorinated elastomers ${ }^{[1,5-6,9,30-31]}$

\begin{tabular}{|c|c|c|c|c|}
\hline \multicolumn{1}{|c|}{ Type } & $\begin{array}{c}\text { Temperature of continuous service } \\
\left({ }^{\circ} \mathbf{C}\right)\end{array}$ & $\% \mathbf{F}$ & $\begin{array}{c}\boldsymbol{T}_{\mathbf{g}} \\
\left({ }^{\circ} \mathbf{C}\right)\end{array}$ & $\begin{array}{c}\text { Trademark } \\
\text { (supplier) }\end{array}$ \\
\hline $\mathrm{CH}_{2}=\mathrm{CF}_{2} / \mathrm{C}_{3} \mathrm{~F}_{6}$ & -18 to 210 & 66 & -18 & Viton $^{\circledR}$ (Chemours) \\
\hline $\mathrm{C}_{2} \mathrm{~F}_{4} / \mathrm{C}_{3} \mathrm{H}_{6}$ & 0 to 200 & 54 & 0 & Aflas $^{\circledR}$ (AGC) \\
\hline $\mathrm{C}_{2} \mathrm{~F}_{4} / \mathrm{CF}_{2}=\mathrm{CFOCF}_{3}$ & 0 to 280 & 73 & -2 & Kalrez $^{\circledR}$ (DuPont) \\
\hline $\mathrm{CH}_{2}=\mathrm{CF}_{2} / \mathrm{C}_{3} \mathrm{~F}_{6} / \mathrm{C}_{2} \mathrm{H}_{4}$ & -12 to 230 & 67 & -16 & Daiel $^{\circledR}$ (Daikin) \\
\hline Fluorosilicones & -65 to 175 & 37 & -68 & Silastic $^{\circledR}$ (Dow Corning) \\
\hline Fluorophosphazenes & -65 to 175 & 55 & -65 & NPF $^{\circledR}$ (Firestone) \\
\hline
\end{tabular}

For aeronautic applications (especially seals, gaskets, shafts), fluorinated elastomers are the best candidates to fulfill the stringent thermal (low and high temperatures) and oil resistance requirements (Figure 5). 


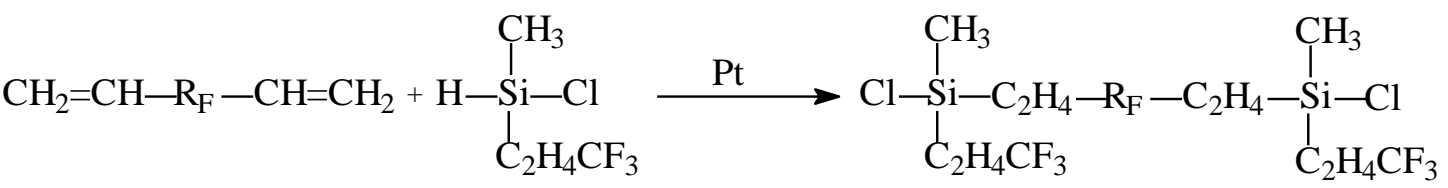

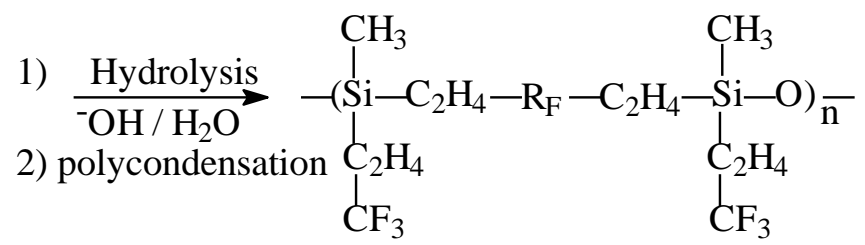

Scheme 4: synthesis of hybrid fluorosilicones by hydrosilylation of fluorinated nonconjugated dienes with fluoroalkylchlorosilanes followed by hydrolysis ${ }^{[33]}$

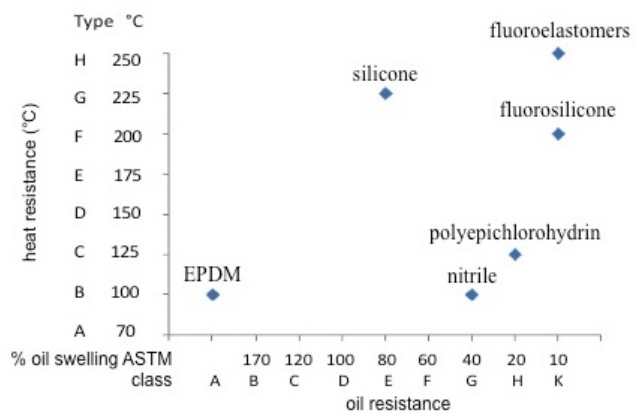

Figure 5: thermal and chemical (to oils) resistance of various elastomers (normalization SAE J 200).

Actually, attractive block copolymers (BCPs) enable to get fluorinated thermoplastic elastomers (TPEs). BCPs from controlled (or pseudoliving) radical polymerizations (CRP), especially iodine transfer polymerization (ITP) pioneered at Daikin ${ }^{[35]}$ followed by its formidable development from mid-90ies, recently named "reversible deactivation radical polymerization", RDRP. Though many works have been investigated on hydrocarbon monomers, that unexpected scientific growth of RDRP contrasts with too few commercially available products derived from such techniques. But, for fluoropolymers, the situation appears more favorable since, from ca. mid 80ies, ITP of fluoroalkenes already led to commercially available TPEs: first Daiel ${ }^{\circledR}$ TPEs commercialized by the Daikin company, ${ }^{[35]}$ followed by Viton ${ }^{\circledR}$ and Tecnoflon ${ }^{\circledR}$, marketed by Dupont (now Chemours) and Solvay Specialty Polymers, respectively. They are synthesized from telechelic bis(iodinated) soft block (with a low glass transition temperature, $\mathrm{T}_{\mathrm{g}}$, of ca. $-35^{\circ} \mathrm{C}$ ) further involved in a chain extension with a Hard segment producing original Hard-Soft-Hard triblock TPEs as artificial lenses ${ }^{[36]}$ (the melting points of hard blocks made of either PVDF, PTFE, poly(E-alt-CTFE) 
or poly(E-alt-TFE) copolymers were $170,327,247$ or $252^{\circ} \mathrm{C}$, respectively). Such Hard-SoftHard triBCPs exhibit crystalline sequences that impart a physical crosslinking (Figure 6). Many other fluoroelastomers are currently crosslinked by various strategies, involving telechelic bisamines, phenolates or peroxides ${ }^{[4,11,37]}$ ) or photocuring. ${ }^{[38]}$

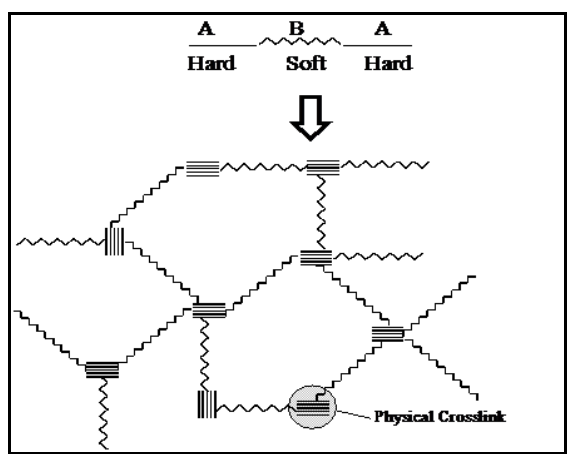

Figure 6: Schematic representation of the crosslinked structure obtained after moulding of a fluorinated block copolymer as TPEs

These BCPs are unique materials based on specific sequences that bring synergetic thermal, mechanical, and chemical properties. In addition, they can supply complementary properties as comprehensively reported in the excellent reviews from Loos et al. ${ }^{[39]}$ or Asandei. ${ }^{[40]}$

Among F-elastomers, commercially available perfluoropolyethers (PFPEs) represent a unique class that displays outstanding properties (chemical inertness to aggressive media such as inorganic and organic bases and acids, halogens, petroleum, and oxidizers, e.g. fluorine and oxygen, high thermal stability preserving their properties at low and high temperatures, and low surface energy $\left.{ }^{[41]}\right)$. The presence of Oxygen linkages gives exceptional softness and mobility to make them amorphous, thus inducing very low $\mathrm{T}_{\mathrm{g}}$ as low as $-100{ }^{\circ} \mathrm{C}$. They are involved as high-performance lubricants such as elastomers, heat transfer fluid lubricants even in aggressive media and pump fluids under demanding conditions. Monofunctional PFPAEs display a high gas solubility making them useful for thin films in cosmetics and barrier creams that offer a very high degree of skin protection and moisture retention to enable the skin breathing. On the other hands, well-defined fluorinated telechelic PFPAEs, generally achieved from $\alpha, \omega$-diol, have led to a wide range of High-Tech applications summarized in Scheme 5. ${ }^{[41]}$ 


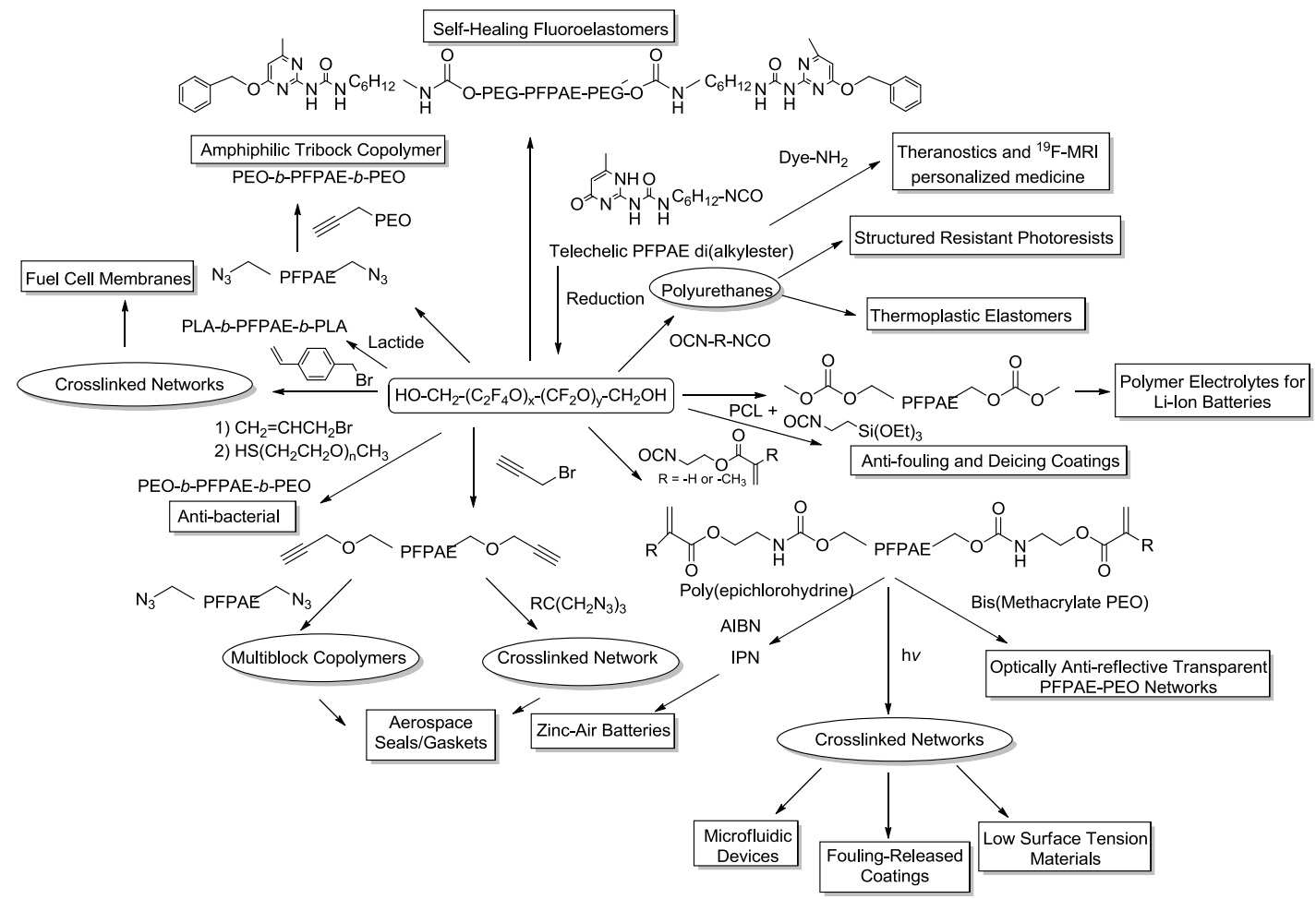

Scheme 5: Summary the uses of telechelic dihydroxyl PFPAEs as precursors for a wide range of intermediates and well-defined fluoropolymers and their applications ${ }^{[41]}$

Among innovative materials based on PFPAEs, poly(PFPAE- $b$-PDMS) multiblock copolymers that combine both PFPAE and dimethylsiloxane (DMS) moieties possess exceptional properties at low and high temperatures. This commercially available product, called Sifel ${ }^{\circledR}$, marketed by the Shin Etsu company, is produced by polyhydrosilylation of telechelic PFPAE dienes with telechelic PDMS bis(silane)s. ${ }^{[9,42]}$ In addition, for processing by molding, such rubbers exhibit easy handling, which are highly desirable than liquid injected molding silanes that require complex mold configurations.

As a matter of fact, besides ITP, more recent techniques involving RDRP of fluorinated monomers have been developed from either borinates ${ }^{[43]}$ or xanthates (named RAFT/MADIX technology). ${ }^{[44]}$ For that latter technique, a comprehensive study on RAFT polymerization of VDF was reported. ${ }^{[44,45]}$ Further, the resulting PVDF-xanthate offered a wide range of architectures (Scheme 6) including block ${ }^{[46]}$ (that self-assembled into micelles in water ${ }^{[47]}$ ), graft, ${ }^{[48]}$ dendrimers, ${ }^{[49]}$ and 4-arm star copolymers. ${ }^{[50]}$ 


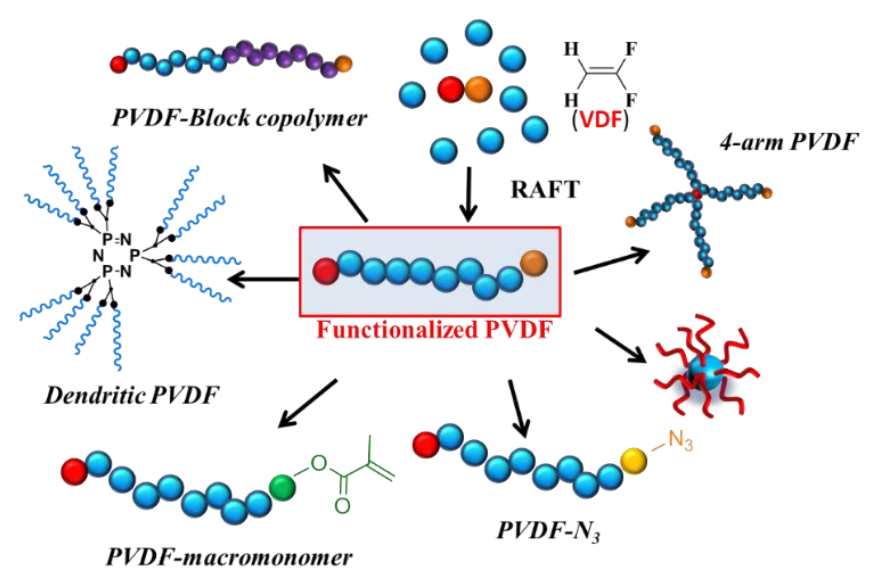

Scheme 6: RAFT polymerization of VDF offering well-designed PVDF architectures ${ }^{\text {[44-50] }}$

More recently, Cobalt mediated radical polymerization of VDF also produced controlled PVDF and subsequently PVDF- $b$-PVAc and PVDF- $b$-PVAc- $b$-PVDF block copolymers. ${ }^{[51]}$

\subsection{FPs and Energy}

The current rapid growth of population, technology and global warming caused by fossil fuel sources has encouraged researchers to find out alternative clean sources of energy. FPs play a major role in strategies to get cleaner sources of Energy. Non-exhaustive ways of energy conversion and energy storage are listed below. ${ }^{[52]}$

\subsubsection{Fuel cell membranes}

Among the different kinds of energy devices, polymer electrolyte membrane fuel cells (PEMFCs, Figure 7) have been widely considered as automotive, portable and stationary power energy conversion sources to reduce several issues associated with the production and consumption of energy. ${ }^{[52]}$ So far, considering the fluorinated membranes, most advanced PEMFC integrate perfluorosulfonic acids (PFSAs) as polymer electrolytes. PFSA membranes (Nafion ${ }^{\circledR}$, Aquivion ${ }^{\circledR}$, Fumion ${ }^{\circledR}$, Flemion ${ }^{\circledR}$, Aciplex ${ }^{\circledR}, 3 \mathrm{M}^{\mathrm{TM}}$, marketed by DuPont, Solvay Specialty Polymers, Fumatech, Asahi Glass Co., Asahi Kasei, and 3M Innovative, respectively) ${ }^{[53]}$ (Figure 8) exhibit high water and proton transport properties, as well as high chemical (especially to acids), thermal, oxidative, and mechanical stabilities.

Residential fuel cell cogeneration systems and fuel cell vehicles came into practical use in 2009 and 2014, respectively.

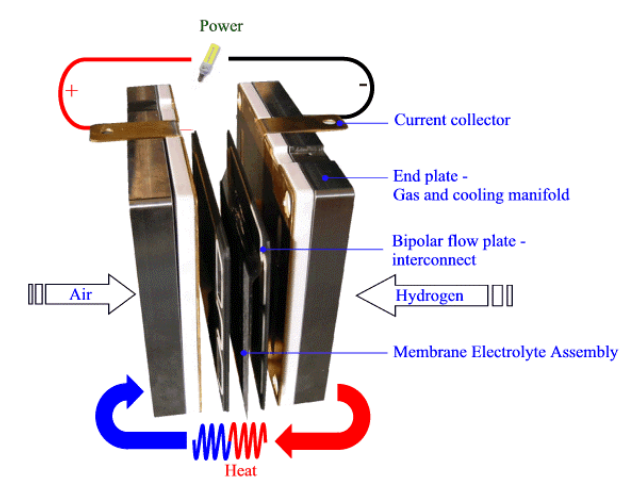


Figure 7: sketch of a membrane electrode assembly of a fuel cell

In addition the production of Mirail cars manufactured by the Toyota company started a couple of years ago and has reached a couple of thousands vehicles in $2017^{\text {[54] }}$ while other automotive companies such as Honda, Mercedes and Hyundai are marketing Clarity, $B$ Class, and Tucson fuel cell electric vehicles, respectively.
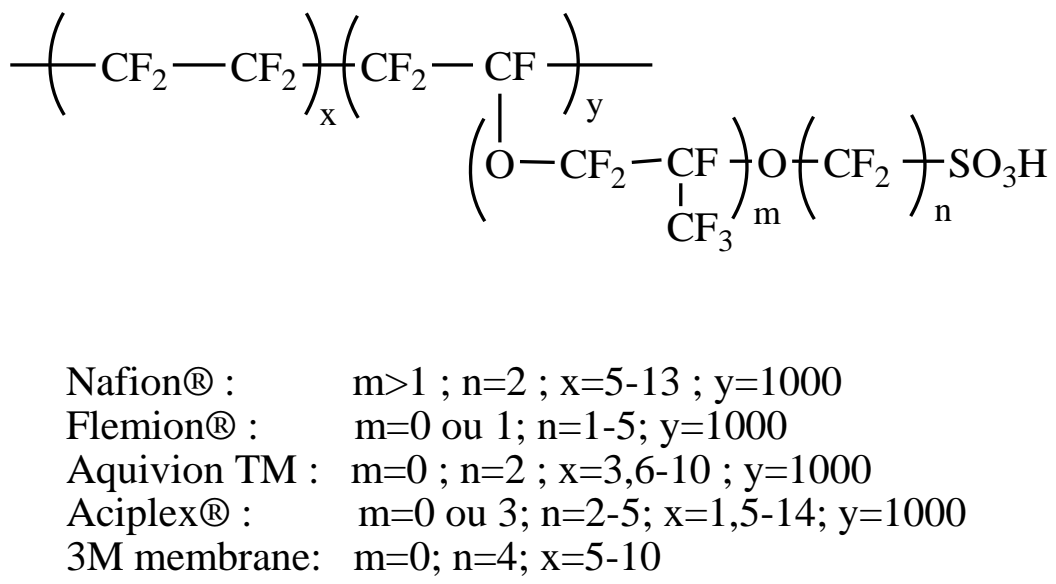

Figure 8: Chemical structure of commercially available perfluorosulfonic acid (PFSA) membranes and their producers ${ }^{[52-53]}$

\subsubsection{Rechargeable Batteries}

Rechargeable batteries are now playing an increasingly essential role in transport and grid applications, but the introduction of these devices arises with different challenges. Thanks to their electrochemical and thermal stabilities and relevant flame retardancy, FPs can be used as specific items in batteries (lithium, sodium and fluoride) ${ }^{[55]}$ : gel or solid polymer electrolytes, binders for electrode materials, or microporous separators for Lithium ion batteries, as well as fluorinated additives for electrolytes. These batteries are of growing interest for energy storage compared to fuel cell (used for energy conversion). Using noncrystalline fluoropolymers is needed to ensure a faster lithium ion transport. Major requirements for gel electrolytes are to: i) be thermally, chemically and fire resistant, ii) 
solubilize the lithium salt, iii) be electrochemically stable to potentials at least to $5 \mathrm{~V}$, and iv) swell in conventionally used solvents.

\subsubsection{Electroactive (ferro-, pyro- and piezoelectric) devices}

Another featuring topic deals with piezo- or ferroelectric materials for many applications such as sensors (as flexible piezoelectric nanogenerator in wearable self-powered active sensor for respiration and healthcare monitoring), infrared cells, haptics, energy harvesting ${ }^{[56]}$ or in printed electronics: electroactive or electrostrictive copolymer films deposited on substrates to avoid forgery, protection of documents, or onto paper as touch screens, baffles or thin keyboards, as well as for actuators ${ }^{[57]}$ further opening toward many medical applications. ${ }^{[56-57]}$ Among all polymers, the dielectric constant of PVDF is the highest (8) but to reach such a property, PVDF films must be poled to shift its $\alpha$ conformation to the $\beta$ one. However, poly(VDF-co-TrFE) copolymers (with ca. 20-50 mol.\% $\operatorname{TrFE}$ composition) are spontaneously piezoelectric. ${ }^{[24]}$

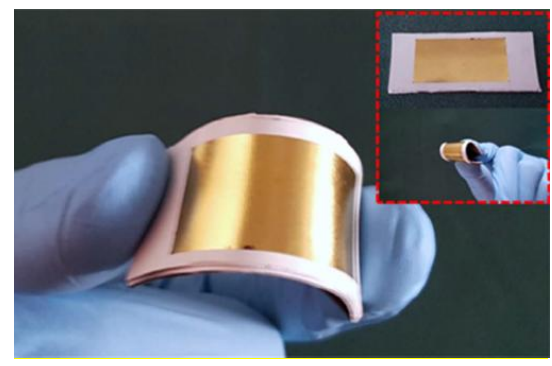

Figure 7: Photograph of piezoelectric active sensor (PEAS) from PVDF nanogenerator ${ }^{[58]}$

Liu et $a l .^{[58]}$ reported a wearable self-powered active sensor for respiration and healthcare monitoring based on a flexible piezoelectric nanogenerator (Figure $9^{[58]}$ ). An electrospinning PVDF thin film on silicone substrate was polarized to obtain flexible nanogenerator and its electrical property was measured. When periodically stretched by a linear motor, the flexible piezoelectric nanogenerator generated an output open-circuit voltage and short-circuit current of up to $1.5 \mathrm{~V}$ and $400 \mathrm{nA}$, respectively.

Enhancement of the energy harvesting performance and dielectric constants of flexible PVDF to produce novel capacitors was reported by Cho et al. ${ }^{[59]}$ by incorporating $16 \mathrm{wt} \%$ of surface-treated $\mathrm{BaTiO}_{3}$ hollow nanospheres. These authors could get very high performances: dielectric constants $\left(\varepsilon^{\prime} \approx 109.6\right)$ and energy density $\left(\mathrm{U} e \approx 21.7 \mathrm{~J} \mathrm{~cm}^{-3}\right)$ with highly retained breakdown strength $\left(\mathrm{E}=3.81 \times 103 \mathrm{kV} \mathrm{cm}^{-1}\right)$. 


\subsubsection{Photovoltaics}

Because of their durability and their resistance to ageing, weather and UV, fluoropolymers have also been involved as protective coatings or «backsheets » in photovoltaic cells. Poly(vinyl fluoride) $\left(\right.$ Tedlar $^{\circledR}$ produced by DuPont ${ }^{[60]}$ ) or PVDF ${ }^{[19]}$ are two commercially available candidates.

\subsection{Fluorinated surfactants}

Fluorinated surfactants are amphiphilic low molar telomers ${ }^{[3]}$. Perfluorooctanoic acid $\left(\mathrm{C}_{7} \mathrm{~F}_{15} \mathrm{CO}_{2} \mathrm{H}, \mathrm{PFOA}\right)$, ammonium perfluorooctanoate (APFO), or perfluorooctyl sulfonic acid $\left(\mathrm{C}_{8} \mathrm{~F}_{17} \mathrm{SO}_{3} \mathrm{X}\right.$, with $\left.\mathrm{X}=\mathrm{K}, \mathrm{Na}, \mathrm{H}, \mathrm{PFOS}\right)$ are the most known while block copolymers have also been reported. ${ }^{[61]}$ These compounds exhibit high performances (quite low surface tensions and critical micellar concentrations) and have been involved in formulations of more than 200 applications ranging from detergents to additives for cosmetics or for paints, textile, leather, fire-fighting foams for hydrocarbon fires, stone treatments, or emulsifiers for polymerization of hydrophobic monomers (especially for fluorinated monomers) in aqueous medium. ${ }^{[61]}$

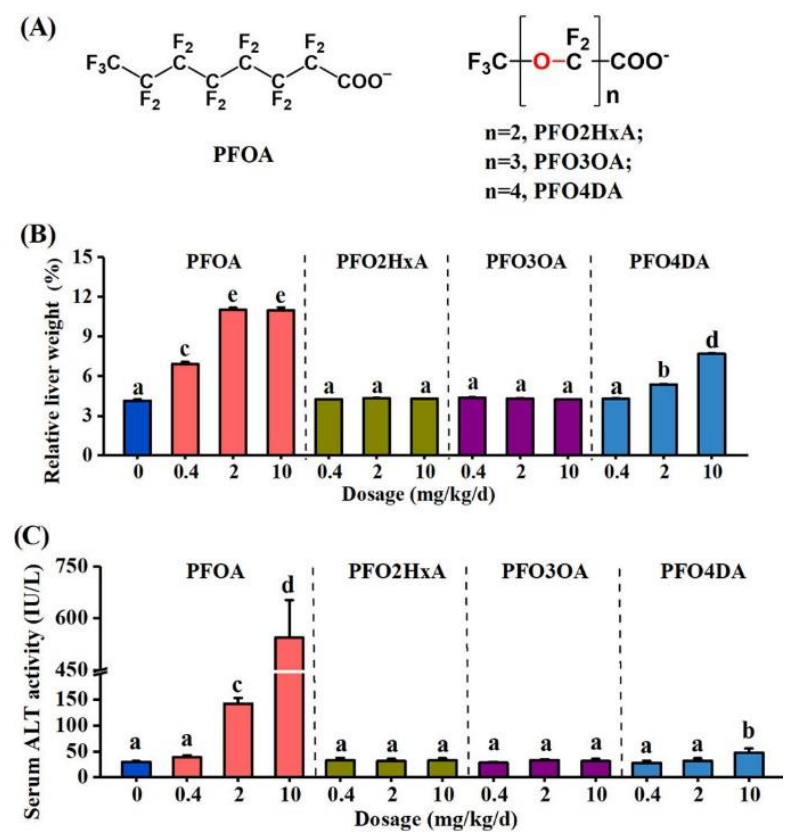

Figure 10: structures of various F-surfactants (A), relative liver weight of mice treated with these surfactants (B), and alanine aminotransferase (ALT) activity in serum of mice treated with these surfactants $(C)$. All data are the means \pm SE $(n=10-12)$, and different letters represent significant differences between groups at $p<0.05$ by one-way analysis of variance (ANOVA) and Duncan's multiple range tests. Reproduced from permission from ${ }^{[63]}$ 
Asahi Glass, Atofina, Ciba (now Archroma), Daikin, DuPont (now Chemours), Omnova, Solvay Specialty Polymers have porduced Surlyn ${ }^{\circledR}$, Forafac ${ }^{\circledR}$, Fluowet ${ }^{\circledR}$, Unidyne ${ }^{\circledR}, Z_{\text {Znyl }}{ }^{\circledR}$ (or Capstone), PolyFox ${ }^{\circledR}$, and Solvera ${ }^{\circledR}$ tradenames, respectively.

However, because of bioaccumulation (their half-lives in human blood are 5.4 and 3.6 years for PFOS and PFOA, respectively, ${ }^{[62]}$ and even 8.5 years for perfluorohexane sulfonate), toxicity and persistency, the PFOA, APFO, and PFOS grades are not produced anymore. Thus, these companies had to modify and even redesign new surfactants. For examples, hexafluoropropylene oxide dimer acid (GenX) and ammonium 4,8-dioxa-3Hperfluorononanoate (ADONA), marketed by Chemours and Dyneon LLC, respectively are recent surfactants, with the following structure: $\mathrm{C}_{3} \mathrm{~F}_{7} \mathrm{OCF}\left(\mathrm{CF}_{3}\right) \mathrm{CO}_{2} \mathrm{H}$ and $\mathrm{CF}_{3} \mathrm{O}\left(\mathrm{CF}_{2}\right)_{3} \mathrm{OCFHCF} \mathrm{CO}_{2} \mathrm{H}$ while other F-surfactants containing perfluorooligo(ether)s, PFOxYA, seem less bioaccumulable ${ }^{[63]}$ (Figure 10).

\subsection{FPS for optics}

Because of their low refractive index, thermal and chemical stabilities, FPs can find interesting applications in optics (waveguides and tuning the refractive indices of cores and claddings for optical fibers $)^{[14,53 f]}$, photonics and high quality transparent coatings. Indeed, the internet shaped in the last decade of the bygone century - with an unbelievable speed - into the backbone of the modern telecommunication society. Started in the late 70ies as an interconnection of four computers only, it exceeded 1.000.000 hosts in 1992 and encompasses today several billion of computers, smartphones and other devices connected to the internet ${ }^{[64]}$, being expected to get 20 billion devices in 2020. ${ }^{[65]}$ In January 2018, more than 4 billion people had access to the internet, being more than $53 \%$ of the world's population at that time (7.593 billion). ${ }^{[66]}$

Actually, one of the major challenges is to get amorphous and transparent materials and FPs bearing cycles are ideal candidates. Indeed, such cycles enable to increase their $\mathrm{Tg}$ values, thus rending them amorphous ${ }^{[14,53 e]}$ (with additional applications as membranes in gas separation ${ }^{[53 \mathrm{f}]}$ ). These suitable perfluorinated (co)copolymers were first pioneered by Asahi Glass Company (now AGC) under Cytop ${ }^{\circledR}$ trademark, the synthesis of which occurs in 6 steps (Scheme 7), from the spontaneous polymerization of a non-symmetrical diene, and Dupont (Teflon®AF from the radical copolymerization of TFE with perfluoro-2,2-dimethyl1,3-dioxole) in the late 80ies. These findings were followed by Solvay Specialty Polymers which manufactures Hyflon®AD (Figure 11). 


$$
\begin{aligned}
& \mathrm{F}_{2} \mathrm{C}=\mathrm{CFCl} \stackrel{+\mathrm{ICl}}{\longrightarrow} \mathrm{CF}_{2} \mathrm{ClCFCll} \stackrel{+\mathrm{TFE}}{\longrightarrow} \mathrm{CF}_{2} \mathrm{ClCFClCF}_{2} \mathrm{CF}_{2} \mathrm{I} \stackrel{+\mathrm{HFPO}}{\longrightarrow} \mathrm{CF}_{2} \mathrm{ClCFClCF}_{2} \mathrm{CF}_{2} \mathrm{OCF}\left(\mathrm{CF}_{3}\right) \mathrm{C}(=\mathrm{O}) \mathrm{F} \\
& \stackrel{-\mathrm{COF}_{2}}{\longrightarrow} \mathrm{CF}_{2} \mathrm{ClCFClCF}_{2} \mathrm{CF}_{2} \mathrm{OCF}=\mathrm{CF}_{2} \stackrel{-\mathrm{Cl}_{2}}{\longrightarrow} \mathrm{CF}_{2}=\mathrm{CFCF}_{2} \mathrm{CF}_{2} \mathrm{OCF}=\mathrm{CF}_{2}
\end{aligned}
$$

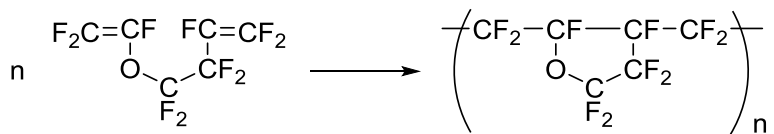

Scheme 7: industrial synthesis of Cytop ${ }^{\circledR}$ polymer from the radical addition of iodine monochloride onto CTFE followed by a functionalization into a non-conjugated diene

Though their productions are limited, these products also exhibit exceptional thermal stability and high Tg (Table 4) that increases with the dioxole content.

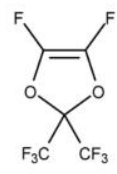

2,2-bis(trifluoromethyl)4,5-difluoro-1,3-dioxole

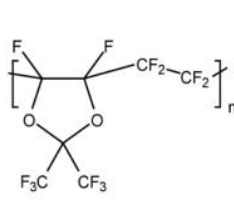

Teflon AF

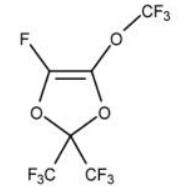

2,2-bis(trifluoromethyl)-4-fluoro5-trifluoromethoxy-1,3-dioxole

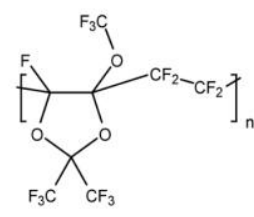

Hyfion AD

Figure 11: Chemical structures of fluorodioxolane monomers (top) and their copolymers with TFE (bottom): Teflon ${ }^{\circledR} \mathrm{AF}$ and Hyflon ${ }^{\circledR} \mathrm{AD} .{ }^{[14]}$

Table 4: Physical Properties of amorphous Teflon ${ }^{\circledR}$ AF, Hyflon ${ }^{\circledR}$ AD, and Cytop ${ }^{\circledR}$ copolymers for optics

\begin{tabular}{lccccc} 
& 1600 & 2400 & $60 \mathrm{X}$ & $80 \mathrm{X}$ & \\
& & & & & \\
\hline $\mathrm{T}_{\mathrm{g}}\left({ }^{\circ} \mathrm{C}\right)$ & 160 & 240 & 125 & 140 & 108 \\
Refractive index & 1.31 & 1.29 & 1.33 & 1.32 & 1.34 \\
Density $\left(\mathrm{g} / \mathrm{cm}^{3}\right)$ & 1.78 & 1.67 & 1.93 & 1.80 & 1.84 \\
Dielectric constant $(\varepsilon)$ & 1.93 & 1.90 & 1.87 & 2.00 & $2.1-2.2$
\end{tabular}

\subsection{FPs in organic electronics}


The majority of electronic devices is silicon-based, enabling fast switching processes necessary to perform information processing. In contrast, organic electronics uses organic materials usually processed by patterned stacks. To prepare such assemblies, the solubility of the material for each layer must be tuned taking into account the properties of the neighboring layers. Transistors shall be as small as possible because their performance scales inversely with dimension, and higher degrees of integration are generally searched. ${ }^{[67]}$ Thus, very homogeneous, smooth, uniform, and thin (3-1000 nm) polymer films and tiny features must be achieved.

Table 5: Comparison of physical properties and gas separation properties at $35{ }^{\circ} \mathrm{C}$ of perfluorodioxolanes [Poly(PFMD) and poly(PFMMD)] and commercially available glassy perfluoropolymers

Permeability (barrer) Selectivity

\begin{tabular}{ccccccccc}
\hline Polymer & $\mathrm{T}_{\mathrm{g}}\left({ }^{\circ} \mathrm{C}\right)$ & $\mathrm{FFV}^{\mathrm{b}}$ & $\mathrm{He}$ & $\mathrm{H}_{2}$ & $\mathrm{~N}_{2}$ & $\mathrm{CO}_{2}$ & $\mathrm{He} / \mathrm{CH}_{4}$ & $\mathrm{H}_{2} / \mathrm{CO}_{2}$ \\
Poly(PFMD) & 111 & 0.21 & 210 & 50 & 0.71 & 5.9 & 1650 & 8.4 \\
Poly(PFMMD) & 135 & 0.23 & 560 & 240 & 7.7 & 58 & 280 & 4.1 \\
Teflon AF 1600 & 162 & 0.31 & & 550 & 110 & 520 & & 1.1 \\
Hyflon AD 80 & 134 & 0.23 & 430 & 210 & 24 & 150 & 36 & 1.4 \\
Cytop & 108 & 0.21 & 170 & 59 & 5.0 & 35 & 84 & 1.7 \\
a P(FMMD) stands for perfluorodioxolane & & & & &
\end{tabular}

Semifluorinated polymers can also find potential application in organic electronics. Organic field effect transistors (OFETs) are employed for basic electronic devices that need both semiconducting polymers and dielectric polymers. The interface between the materials used must be optimized to ensure a sufficiently high charge carrier transport. Figure 12 illustrates the schematic structure of a typical OFET configuration and exhibits the positions of the active layers. Even a single OFET requires semiconductor, conductors and dielectric layers. 

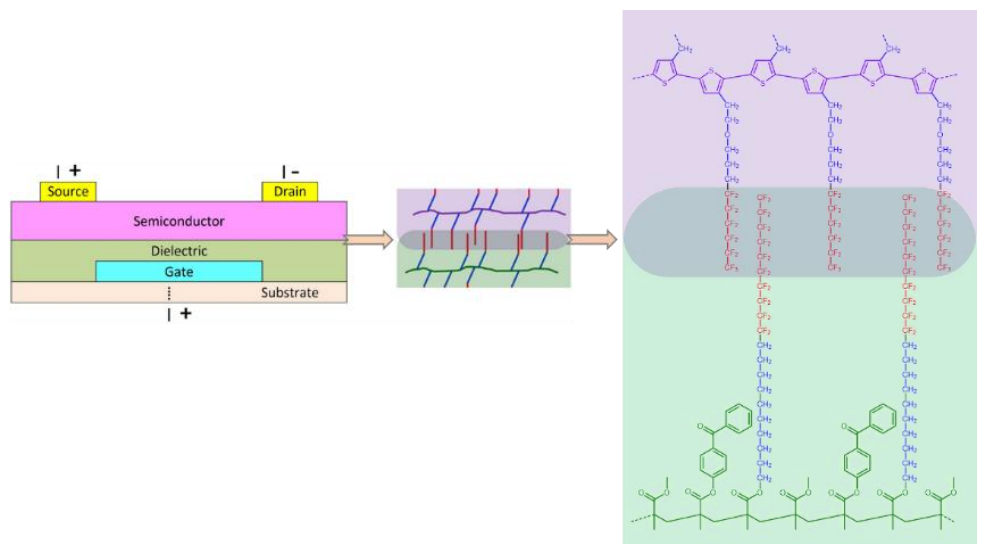

Figure 12: Scientific concept for the design of the semiconductor/dielectric interface in an organic field effect transistor studied here.

Collard's team ${ }^{[68]}$ pioneered the synthesis and characterization of various poly(thiophene)s containing fluorinated side-chains (Figure 13).
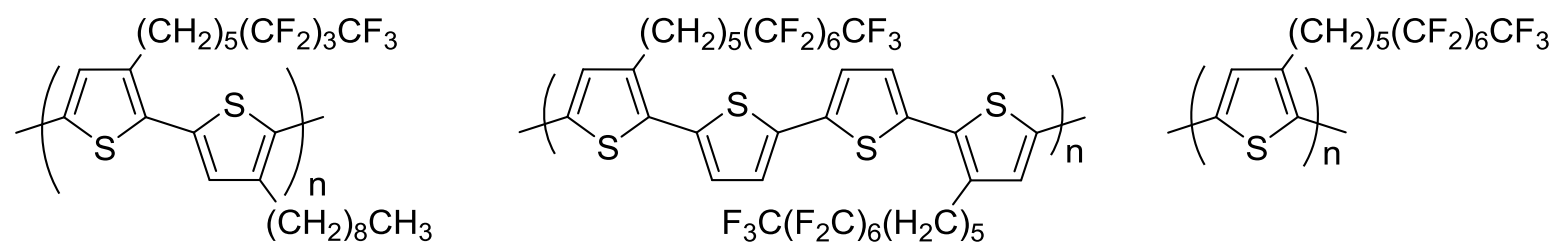

Figure 13: Poly(thiophene) semiconductors with semifluorinated side chains. ${ }^{[68]}$

\subsection{FP Composites}

Binding ceramics, inorganic fillers or clays to FPs is a real challenge and a quasi-exhaustive review reports various strategies and applications of the resulting nanocomposites ${ }^{\text {[69] }}$ (Figure $14)$.

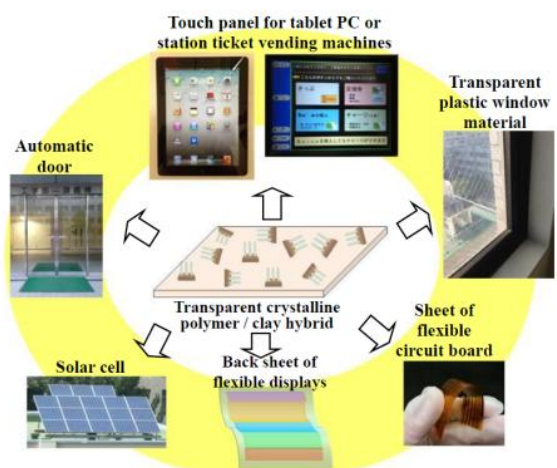


Figure 14: wide range of application from PF-fillers-clay nanocomposites ${ }^{[69]}$ (reproduced from the permission of Elsevier)

\subsection{Fluorinated Shape Memory Polymers}

Quite a few FPs have shown shape memory properties. One example has been chosen from poly(VDF-co-CTFE)-g-PEGMA graft copolymers. ${ }^{[70]}$ A more recent work deals with PVDF flat strip specimens bend into a closed loop in $0.2 \mathrm{~s}$ and further into a coil in just $0.4 \mathrm{~s}{ }^{\text {[75] }}$ (Figure 15). Then specimen recovered its flat shape within $0.4 \mathrm{~s}$ when exposed to air. PVDF samples showed consistent shape recovery without fatigue even after hundreds of cycles.

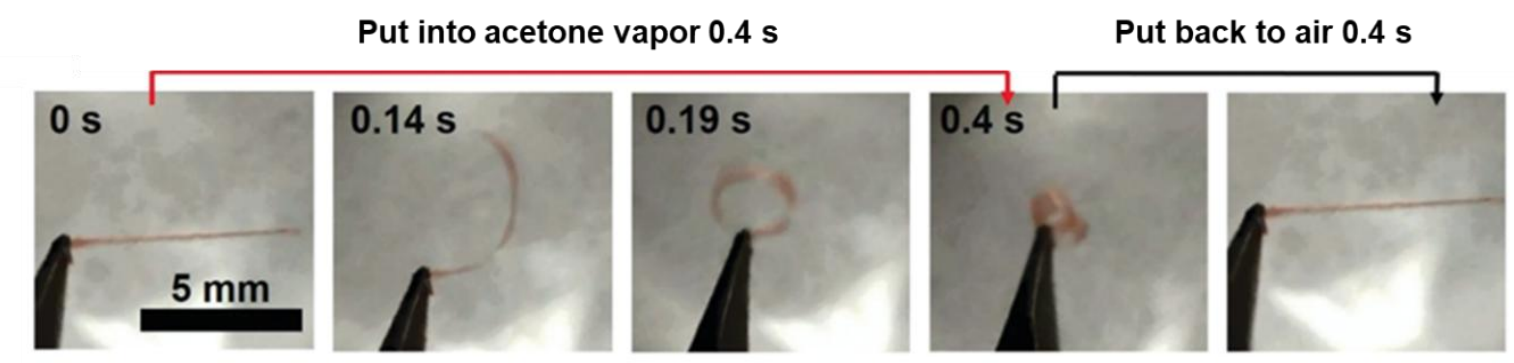

Figure 15: A top-view photograph showing a responsive process of a transparent PVDF strip (1 mm x $7 \mathrm{~mm}$ x $3 \mathrm{~mm}$ ). Reproduced with permission from Ref. ${ }^{70}$ Copyright (2018) Royal Society of Chemistry. Materials Horizons, 2018, 5, 99-107.

\subsection{FPs for Biomedical applications}

Many biomedical applications of FPs (suture wires, stems, artificial veins, controlled drug delivery systems, tissue engineering, microfluidic and artificial muscle actuators, etc...) have been reported and well-reviewed in an excellent review. ${ }^{72}$

\section{Conclusions and Perspectives}

Thanks to their outstanding properties, FPs are still used in many specific conditions (i.e. under corrosive, ageing and harsh media) and cannot be replaced by other materials. This non-exhaustive browse supplies several recent innovative achievements from FPs: thermoplastic elastomers for aerospace and car industries, components for energy, coatings, optically and transparent films. The market of such specialty polymers, in full expansion, has been increasing since three decades with an average annual growth of 6-8\% in the world production. ${ }^{[16]}$. PTFE dominates the market while FEP is expected to increase much faster than the other FPs. In spite of their price linked to the small volume of production, many researches are still going on and in a wide range of topics. Though their durability is still an 
issue, their recycling or finding routes for their degradation (e.g., mineralization ${ }^{[73]}$ ) has already started ${ }^{[18]}$ (Figure 16). The challenges are still numerous. Several targets are listed hereafter:

- a better design of functional FPs by choosing the appropriate partner of commercially available fluoroalkenes (e.g. vinyl ethers for CTFE or TFE);

- finding out new and easier ways of crosslinking; combining FPs and biosourced comonomers or reactants;

- deeply studying the nanostructuration or nanoconfinement for membranes or electroactive films; synthesizing innovative fuel cell membranes based of new polymers stable in acidic media and at medium to high temperatures (110-150 $\left.{ }^{\circ} \mathrm{C}\right)$ and at low relative humidity (ca. 25-30 \%) or in alkaline medium;

- developing novel flame-resistant Li conducting-electrolytes and separators for Lithium ion batteries;

- decreasing Tg values of elastomers for aerospace applications, as well as maintaining both their chemical inertness in specific solvents of aeronautics and their thermostability;

- formulation of original non solvent-paints stable to UV, and crosslinkable at room temperature;

- preparing novel non-toxic, non-persistent and non-bioaccumulative surfactants;

- coatings of optical fibers which contain a perfluorinated group enabling to tune refractive index and bringing an enhanced hydrophoby;

- decreasing the price of these products.

Japanese, Chinese and American companies have much invested in the last twenty years in $\mathrm{R} \& \mathrm{D}$ of FPs. Enormous resources of $\mathrm{CaF}_{2}$ (as raw material for the fluorine chemistry chain) It is expected that further issues will be overcome and more advances reached while many academic and industrial researchers will devote many efforts into this stimulative research area of FPs in the coming decades.

\section{Acknowledgements}

The author thanks all coworkers cited in the references, the French National Agency (ANR; PREMHYS and FLUPOL-ANR-14-CE07-0012 projects), and European Union (SENSOILS647857), the French National Network (GIS), and various French and foreign companies for their financial contributions. 


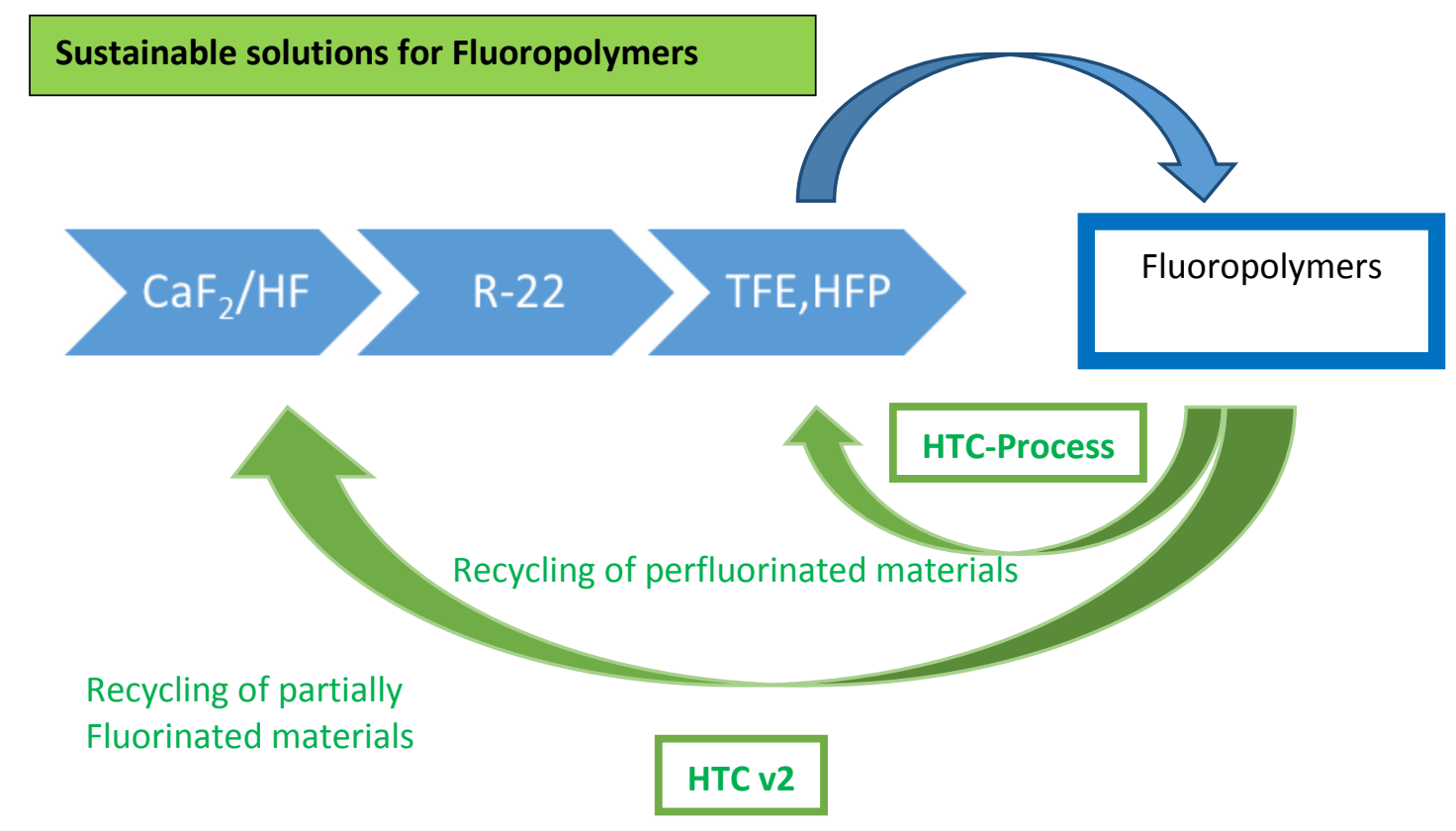

Figure 16: Fluoropolymer recycling loop (adapted from ref. ${ }^{[18]}$ )

\section{References}

[1] a) J. Scheirs, Ed., Modern Fluoropolymers, Wiley Interscience, New York, 1997, pp 435485; b) G. Hougham, P.E. Cassidy, K. Johns, J. Davidson, Eds Fluoropolymers: Synthesis and Applications. Plenum Publish, New York, USA, 1999.

[2] a) S. Ebnesajjad, Ed.; Fluoroplastics, Plastic Design Library Series, Norwich, New-York, 2003; b) S. Ebnesajjad, Ed. Fluoroplastics Melt Processible Fluoropolymers The Definitive User's Guide and Databook, Volume 2, Plastics Design Library, Norwich, New York, USA, 2003.

[3] B. Améduri, B. Boutevin, Eds, Well Architectured Fluoropolymers: Synthesis and Applications. Elsevier, Amsterdam, 2004.

[4] A.L. Moore, Ed., Fluoroelastomer Handbook; The Definitive User's Guide and Data Book Norwich, William Andrew Publishing, 2006.

[5] D.W. Smith, S. T. Iacono, S. S. Iyer, Eds, Handbook of Fluoropolymer Science and Technology; Wiley, New York, 2014.

[6] J. Gardiner; Aust. J. Chem. 2015, 68, 13-22.

[7] J.G. Drobny, Ed, Fluoroelastomers Handbook, The Definitive User's Guide, Second ed., William Andrew Publishing, Oxford, 2016.

[8] B. Améduri, H. Sawada, Eds.; Fluorinated Polymers, Volume 2, Applications (Polymer Chemistry Series); The Royal Society of Chemistry, Cambridge, 2016.

[9] B. Améduri, Chem. Eur. J., 2018, 24, 18830.

[10] S.V. Sokolov, I.G. Kolokol'tseva, Polym. Sci. Ser A, 1996, 225-231 (translated from Vysokomol. Soed.1996, 38, 400-406).

[11] B. Améduri, B. Boutevin, G. Kostov, Prog. Polym. Sci., 2001, 26, 105-187; c) B. Améduri, B. Boutevin, J. Fluorine Chem., 2005, 126, 221-234.

[12] Y. Wang, Y. Bai, RSC Adv. 2016, 6, 53730-53748. 
[13] Z. Cui, E. Drioli, Y.M. Lee, Recent progress in fluoropolymers for membranes. Progr. Polym. Sci. 2014, 39, 164-198.

[14] Y. Okamoto, F. Mikes, K. Koike, Y. Koike, Amorphous perfluoropolymers, in ref [5]; chapt. 16, pp 377-391.

[15] G. J. Puts, P. Crouse, B. Améduri, Chem. Rev., 2019, 118, 1763-1805

[16] IHS Markit. Fluoropolymers. Chem Econ Handb 2019. https://ihsmarkit.com/products/fluoropolymers-chemical-economics-handbook.html (accessed August 27, 2019).

[17] R. Krämer, M.D. Schlipf, Fluoropolymers. Kunststoffe Int 2016:82-6. https://www.kunststoffe.de/en/journal/archive/article/social-megatrends-give-

fluoropolymers-a-boost-1800781.html? search.highlight=fluoropolymer (accessed September 2019).

[18] R. Dams, K. Hintzer in ref [8], Industrial Aspects of Fluorinated Oligomers and Polymers, in Fluorinated Polymers: Volume 2: Applications. RSC, Oxford, Chapt. 1, 2016; pp 1-31.

[19] J.T. Goldbach, R. A. Sanayei, W. He, J. Henry, W. Kosar, A. Lefebvre, G. O’Brien, D. Vaessen, K. Wood, S. Zerafati, in ref [8], Commercial Synthesis and Applications of PVDF, Volume 2, chapt. 6, pp; 127-157; 2016.

[20] D. A. Hercules, C. A. Parrish, J.S. Thrasher, Research and Non-major Commercial Coand Terpolymers of Tetrafluoroethylene, In Ameduri, B.; Sawada, H., Eds.; Fluorinated Polymers: Volume 2: Applications (Polymer Chemistry Series); The Royal Society of Chemistry, Cambridge, 2016, Chapt. 9, pp 206-264.

[21] F. Boschet, B. Améduri, Chem Rev. 2014, 114, 927-980.

[22] a) D.A. Seiler, PVDF in the Chemical Process Industry, in J. Scheirs Ed., Modern Fluoropolymers, chap. 25, 1997, p. 487-506, Wiley, New York; b) J. S. Humphrey, R. AminSanayei; "Vinylidene Fluoride Polymers"; In H. F. Mark., Ed.; Encyclop. Polym. Sci. Techn., 3rd ed.; 2004, Wiley, New York, Vol. 4, pp 510-533.

[23] a) B. Améduri; Chem Rev., 2009, 109, 6632-6686; b) B. Améduri, Science of Synthesis Vol. 24; E. Schaumann, M. Brøndsted Nielsen, ed. 2014, pp 317-352.

[24] T. Soulestin, V. Ladmiral, F. Santos-Dominguez, B. Améduri, Progr. Polym Sci. 2017, $72,16-60$.

[25] a) Y. Patil, B. Améduri, Prog. Polym. Sci. 2013, 38, 703; b) S. Banerjee, B. Améduri, Frontiers of Organofluorine Chemistry, I. Ojima, ed., World Scientific, 2020 (in press, ISBN 978-1-78634-732-9).

[26] M. Wehbi, S. Banerjee, A. Manseri, A. Mehdi, A. Alaaeddine, A. Hachem, B. Améduri Macromolecules, 2017, 50, 9329-9339.

[27] M. Wadekar, Y. R. Patil, B. Améduri, Macromolecules, 2014, 47, 13-25.

[28] S. Banerjee, M. Wehbi, A. Manseri, A. Mehdi, A. Alaaeddine, A. Hachem, B. Améduri, ACS Appl. Mater. Interf., 2017, 9, 6433-6443.

[29] a) A. Alaaeddine, J. Vergnaud, J. Rolland, A. Vlad, J.-F. Gohy, B. Améduri, Polym. Chem., 2015, 6, 6021-6028; b) F. Boujioui, F. Zhuge, H. Damerow, M. Webhi, B. Améduri, J.-F. Gohy, J. Chem. Mat. 2018, 6, 8514-8522; c) M. Wehbi, G. Dolphin, J. Brassinne, J.F. Gohy, B. Améduri Macromolecules, 2019, 52, 3056-3065.

[30] M. Wehbi, A. Mehdi, A. Allaeddine, C. Negrell, G. David, B. Améduri, Appl. Mater. Interf. (in press, doi.org/10.1021/acsami.9b16228).

[31] T. Hoshino, Y. Morizawa, Fluorinated Specialty Chemicals: Fluorinated Copolymers for Paints and Perfluoropolyethers for Coatings, in Ref. [8], chapt. 5, pp. 110-126.

[32] A.T. Worm, W. Grootaert, Encycl. Polym. Sci. Techno., 2001, 2, 577- 590. 
[33] a) M. Owen, Poly[methyl(3,3,3-trifluoropropyl)siloxane], in ref [5]; chapt. 9; pp 183200; b) C. Pasquet, C. Longuet, S. Hamdani-Devarennes, B. Améduri, F. Ganachaud, Silicone Surface Science, M.J. Owen, R. Dvornic, eds., Springer, Washington, USA, 2012, Chapt. 5, pp. 115-178.

[34] a) H. R. Allcock, Chemistry and Applications of Polyphosphazenes; John Wiley \& Sons, Hoboken, NJ, 2003; b) H. R. Allcock, Fluorinated polyphosphazenes, in ref [5], chapter 1, pp $1-20$; c) Structural Diversity in Fluorinated Polyphosphazenes: Exploring the Change from Crystalline Thermoplastics to High-performance Elastomers and Other New Materials; in ref [8], Vol. 2; Chapter 3, pp 54-79.

[35] a) M. Tatemoto, in Polymeric Materials Encyclopedia; J. C. Salamone, Ed.; CRC: Boca Raton, FL, 1996, Vol. 5, pp 3847-3862; b) M. Tatemoto, T. Shimizu, Thermoplastic Elastomers. in Modern Fluoropolymers; Scheirs, J., Ed.; Wiley: New York, 1997; Chapter 30, pp 565-576.

[36] a) Yagi, T.; Tsuda, N.; Noguchi, T.; Sakaguchi, K.; Tanaka, Y.; Tatemoto, M. Eur. Patent-1990/Appl. 0,422,644 (assigned to Daikin Industries, Ltd.); b) https://www.daikin.com/chm/products/rubber/index.html (accessed on April, 30 ${ }^{\text {th }}$, 2018).

[37] A. Taguet, B. Améduri, B. Boutevin, Adv. Polym. Sci., 2005, 184, 127-211.

[38] B. Améduri, A. Vitale, R. Bongiovanni, Chem. Rev., 2015, 115, 8835-8866.

[39] V.S. D. Voet, G. ten Brinke, K. Loos, J. Polym. Sci., Part A: Polym. Chem. 2014, 52, 2861-2877.

[40] A. Asandei, Chem. Rev., 2016, 116, 2244-2274.

[41] C. M. Friesen, B. Améduri, Progr. Polym Sci. 2018, 81, 238-280.

[42] Osawa Y, Sato S, Matsuda T. Fluororubber composition. US 2015/024007S (assigned to Shin Etsu Chemical Co. Ltd).

[43] T.C. Chung, Synthesis of fluoropolymers using borane-mediated control radical polymerization for energy storage applications, in ref [6]; chapter 12, pp 291-314;

[44] M. Guerre, O. Gimello, K. Parra, B. Ameduri, V. Ladmiral, Macromolecules, 2015, 48, $7810-7822$

[45] a) M. Guerre, S. M. Wadihur Rahaman, B. Améduri, R. Poli, V. Ladmiral, Macromolecules, 2016, 49, 5386-5396 ; b) M. Guerre, G. Lopez, T. Soulestin, C. Totée, B. Améduri, G. Silly, V. Ladmiral, Macromol. Chem. Phys. 2016, 217, 2275-2285.

[46] M. Guerre, B. Améduri, V. Ladmiral, R. Poli, Polym. Chem. 2016, 7, 6918-6933 ; b) M. Guerre, M. Uchiyama, E. Folgado, M. Semsarilar, B. Améduri, K. Sato, M. Kamigaito, V. Ladmiral, ACS MacroLetters, 2017, 6, 393-398; c) S. Banerjee, Y. Patil, O. Gimello, B. Améduri, Chem. Comm., 2017, 53, 10910-10913.

[47] M. Guerre, J. Schmidt, Y. Talmon, B. Améduri, V. Ladmiral, Polym. Chem. 2017, 8, 1125-1128.

[48] M. Guerre, B. Améduri, V. Ladmiral, Polym. Chem., 2016, 7, 441-450.

[49] a) E. Folgado, M. Guerre, C. Bijani, V. Ladmiral, A.-M. Caminade, B. Améduri, A Ouali, Polym. Chem. 2016, 7, 5625-5629 ; b) E. Folgado, M. Guerre, N. Mimouni, V. Collière, C. Bijani, K. Moineau-Chane Ching, A.-M. Caminade, V. Ladmiral, B. Améduri, A. Ouali, ChemPlusChem, 2019, 84, 78-84.

[50] a) G. Lopez, M. Guerre, J.P. Habas, B. Améduri, V. Ladmiral, Polym. Chem. 2017, 8, 3045-3049; b) D.E. Apostolides, C.S. Patrickios, T. Sakai, M. Guerre, G. Lopez, B. Ameduri, V. Ladmiral, M. Simon, M. Gradzielski, D. Clemens, B. Ernould, A. Vlad, J-F. Gohy, Macromolecules, 2018, 51, 2476-2488.

[51] a) S. Banerjee, V. Ladmiral, A. Debuigne, C. Detrembleur, R. Poli, B. Améduri, Angew. Intern. Ed. 2018, 57, 2934 -2937; b) P. Falireas, V. Ladmiral, A. Debuigne, C. Detrembleur, R. Poli, B. Améduri, Macromolecules, 2019, 52, 1266-1276. 
[52] T. Nakajima, H. Groult, Eds., Advanced Fluoride-Based Materials for Energy Conversion, Elsevier, Amsterdam, 2015.

[53] a) M.A. Hickner, H. Ghassemi, Y.S. Kim, B.R. Einsla, J.E. McGrath Chem. Rev., 2004, 104, 4587-4612; b) A. Ghielmi , P. Vaccarono, C. Troglia, V. Arcella; J. Power Sources 2005, 145, 108-115; c) M. Yoshitake, A.Watakabe, Perfluorinated Ionic Polymers for PEFCs, Adv. Polym. Sci. 2008, 215, 127-155; d) W. Grot, Fluorinated Ionomers, 2011, Elsevier, Amsterdam, 2011, ISBN 9781437744576; e) S. Banerjee, A. Ghosh; Semifluorinated aromatic polymers and their properties; in B. Ameduri, H. Sawada, Eds., Fluorinated Polymers, volume 1, Chapter 5, 103-189; RSC, Oxford, 2016; f) E. Drioli, L. Giorno, E. Fontananova, Eds,; Comprehensive Membrane Science and Engineering, Vol.1; Membrane Science and Technology; Elsevier, Amsterdam, 2017; g) A. Kusoglu, A. Z. Weber, Chem. Rev., 2017, 117, 987; h) T. Hirai, Y. Morizawa; Fluorinated Ionomers and Ionomer Membranes: Monomer and Polymer Synthesis and Applications ; in ref [8], chapter 8, pp 179-205.

[54] Y. Tanaka, Development of the Mirai Fuel Cell vehicle; In Hydrogen Energy Engineering, A Japanese Perspective in K. Sasaki, H.W. Li, A. Hayashi, J. Yamabe, T. Ogura, S.M. Lyth, (Eds); chapter 34; pp 461-476, 2016, Springer, Tokyo.

[55] a) K. Ozawa, Lithium ion rechargeable batteries; Materials, Technologies and New Applications, Wiley-VCH, 2009, Weinheim; b) R.A. Sanayei, W. He, Applications of polyvinylidene fluoride binders in lithium ion batteries, in ref [52], chapt. 10 pp 231-242; c) H. Zhang, C. Li, M. Piszcz, E. Coya, T. Rojo, L.M. Rodriguez-Martinez, M. Armand, Z. Zhou, Chem Soc. Rev., 2017, 46, 797-815; c) J. C. Barbosa, J. P. Dias, S. Lanceros-Méndez, C. M. Costa, Membranes, 2018, 8, 45.

[56] a) C. M. Costa, M.M. Silvab, S. Lanceros-Mendez; RSC Adv., 2013, 3, 11404-11417; b) C. R. Bowen, H. A. Kim, P. M. Weaver, S. Dunn, Energy Environ. Sci., 2014, 7, 25-44; c) Y. Zhang, M. Xie, V. Adamaki, H. Khanbareh, C. R. Bowen, Chem. Soc. Rev., 2017, 46, 77577786.

[57] L. J. Romasanta, M. A. Lopez-Manchado, R. Verdejo, Progr. Polym. Sci. 2015, 51, 188211.

[58] Z. Liu, S. Zhang, Y. M. Jin, H. Ouyang, Y. Zou, X. X. Wang, L. X. Xie, Z. Li, Semicond. Sci. Technol. 2017, 32, 064004

[59] S. Cho, J. S. Lee, J. Jang, Adv. Mater. Interfaces 2015, 2, 1500098 (1-13).

[60] https://www.dupont.com/products-and-services/membranes-films/pvf-films/brands/tedlarpvf-films.html (accessed on Dec 2019) TEDLAR

[61] F. Boschet, G. Kostov, B. Améduri, J. Fluorine Chem. 2009, 130, 1192-1199.

[62] B. J. Henry, J.P. Carlin, J. A. Hammerschmidt, R. C. Buck, L.W. Buxton, H. Fiedler, J. Seed, O. Hernandez; Integrat. Environ. Assess. Manag. 2018, 14, 316-334.

[63] H. Guo, J. Wang, J. Yao, S. Sun, N. Sheng, X. Zhang, X. Guo, Y. Guo, Y. Sun, J. Dai, Environ. Sci. Technol., 2019, 53, 3929-3937

[64] R. H'obbes' Zakon, Hobbes' Internet Timeline 25, online available at: https://www.zakon.org/robert/internet/timeline/\#Growth [Accessed in November 2019].

[65] F. Tenzer, Anzahl der vernetzten Geräte im Internet der Dinge (IoT) weltweit bis 2020, online available at https://de.statista.com/statistik/daten/studie/537093/umfrage/anzahlder-vernetzten-geraete-im-internet-der-dinge-iot-weltweit/ [Accessed in November 2019].

[66] V. Bouwman, Global Digital Report 2018, online available at https://wearesocial.com/de/blog/2018/01/global-digital-report-2018 [Accessed December 2019].

[67] D. Pospiech, D. Jehnichen, C. Horn, M. Plötner, Self-organizing semifluorinated polymers for organic electronics, in B. Ameduri; S. Fomin, eds, Progress in Fluorine Series, Elsevier, in press. 
[68] a) J. S. Middlecoff, D. M. Collard, Synth. Met., 1997, 84, 221-222; b) L. Li, D.M. Collard, Macromolecules, 2006, 39, 6092-6097; c) B. Wang, S. Watt, M. Hong, B. Domercq, R. Sun, B. Kippelen, D.M. Collard, Macromolecules, 2008, 41, 5156-5165; c)

[69] A. Fujimori "Fabrication of flexible transparent nanohybrids with heat-resistance properties using a fluorinated crystalline polymer" in B. Améduri and H. Sawada, eds; Fluorinated Polymers: From Fundamental to Practical Synthesis and Applications, chapt. 11, vol. 2; "Applications", pp. 301-352; Royal Society of Chemistry, Oxford, 2016.

[70] G.A. Eken, M.H. Acar, Eur. Polym. J., 2019, 114, 249-254.

[71] H. Deng, Y. Dong, C. Zhang, Y. C. Xie, C. Zhang, J. Lin, Materials Horizons, 2018, 5, 99-107.

[72] V. Cardoso, D. Correia, C. Ribeiro, M. Fernandes, S. Lanceros-Méndez, Polymers, 2018, 10, 161.

[73] H. Hori, H. Tanaka, T. Tsuge, R. Honma, S. Banerjee, B. Améduri, Eur. Polym. J., 2017, 94, 322-331. 